\title{
Academic and Career Aspiration and Destinations: A Hong Kong Perspective on Adolescent Transition
}

\author{
Kwok-Tung Tsui (D), Chi-Kin John Lee, King-Fai Sammy Hui, Wai-Sun Derek Chun, \\ and Nim-Chi Kim Chan
}

The Education University of Hong Kong, Hong Kong

Correspondence should be addressed to Kwok-Tung Tsui; kttsui@eduhk.hk

Received 3 April 2019; Revised 6 August 2019; Accepted 9 September 2019; Published 3 November 2019

Academic Editor: Christos Troussas

Copyright ( 2019 Kwok-Tung Tsui et al. This is an open access article distributed under the Creative Commons Attribution License, which permits unrestricted use, distribution, and reproduction in any medium, provided the original work is properly cited.

\begin{abstract}
Understanding the academic and career aspirations of adolescents and their destinations could inform policy makers and educators about how best to provide support at society and school levels to facilitate adolescents transitioning from school to further education and work. The current qualitative study investigates seven senior secondary students from three schools with varying intakes of student ability under the "Secondary School Places Allocation System" in Hong Kong. By employing a Systems Theory Framework, the study looked into the academic and career aspirations of these students and tracked their destinations immediately after secondary school graduation. Findings show that the academic and career aspirations of adolescents and their destinations are shaped by prevailing preferences for attaining higher qualifications, preferably a bachelor's degree, parental and others' influences, and outcomes of public examination results. The implications of enhancing support for the societal, school, and career- and life-planning education of individuals are discussed.
\end{abstract}

\section{Introduction}

Transition from school to work is one of the key transitions in life. In recent years, however, increasing educational opportunities are seeing a reduction in the tendency of secondary school graduates to join the workforce immediately after graduation. Marks et al. [1] with regard to the expectations and destinations of senior secondary students in New South Wales in Australia suggest that "the main activities of Year 12 completers were full-time university study $(46 \%)$ and full-time vocational study at a Technical and Further Education (TAFE) institution (11\%) as well as full-time work (22\%) consisting of apprenticeships and trainee work and part-time work (14\%)." Marks et al. further note that a high proportion of students were expected-by their parents and teachers-to pursue university study instead of engaging in vocational study or training (p. xi). A follow-up study showed that $52.5 \%$ of Year 12 graduates pursued a bachelor's degree as their postschool destination ([2], p. x). In the United States, a common expectation among senior secondary (high) school students and their parents is that the completion of secondary schooling leads to studying at a university or a college [3]. In Hong Kong, studies have indicated that $70 \%, 44 \%$, and $29 \%$ of senior secondary students considered a degree, higher diploma, and associate degree, respectively, as their further education destination. On the other hand, $58 \%, 41 \%$, and $20 \%$ of parents suggest that their children consider a degree, higher diploma, and associate degree, respectively ([4]; p. 111 and 117). Understanding the academic and career aspirations of adolescents and their destinations could inform policy makers and educators about how best to provide support at society and school levels to facilitate adolescents transition from school to further education and work. This qualitative study investigates the academic and career aspirations of senior secondary students from a sample of schools with varying intakes of students according to a student's allocation band under the Secondary School Places Allocation System [5] and tracked their destinations immediately after secondary school graduation. 


\section{Literature Review}

2.1. Social Cognitive, Person-Environment Fit, and Developmental Theories. In general, the smooth school-towork transition of adolescents depends on their individual background and their perception of context. Their choices are shaped by changing environments, significant others, and existence of support and/or barriers. A number of key theories have assisted in the creation of a theoretical backdrop to career development and shed light on the ways in which adolescents cope with the challenges of school-to-work transition [6]. Among these are social cognitive, person-environment fit, and developmental theories. Some decades ago, Bandura [7] constructed his social learning theory, which focused on adolescents as active agents who interacted with their environments. The career choices and paths available to adolescents tend to be influenced by their individual beliefs, past and present contexts, planned and unplanned incidents, and learning experiences $[8,9]$. In this light, and as a follow-up to his earlier social learning theory, Bandura [10] expanded and built on his previous work, which developed into what has become known as social cognitive theory-with its emphasis on outcome expectations, self-efficacy, and goals. Adolescent vocational interests, which may be affected by the support of significant others and by the existence of barriers, are then assumed to be translated into goals followed by actions [11].

Following a somewhat different line of thinking, the person-environment fit theory emerged from Holland's approach [12] and Dawis and Lofquist's [13] Theory of Work Adjustment, which highlighted the imperative of occupational choice and an interactive and reciprocal process between the individual and the work environment (Donald, 2008). These models shed light on how the adolescent's selfknowledge and the environment-especially the workplace-shaped their choices and eventual adjustments. The career development theory was built upon the notion that school-to-work transition is a developmental process [14]; adolescents are able to make choices and cope with change through acquiring competences and skills such as selfknowledge, seeking career information and possibilities, decision-making, planning, and problem-solving [15].

2.2. Transition Systems and Systems Theory Framework. Raffe's [16] transition systems refers to features of a country or jurisdiction's institutional arrangements which help shape young people's education-work transitions. Raffe further proposed a conceptual framework to review and study transition systems which comprises four levels of analysis: individual transition process and outcomes, national transition patterns, institutional and structural dimensions of transition systems, and typologies of transition system. Transition systems in learning usually focus on educational experience and outcomes measured at the microlevel ([16]; p. 281), with student choice in terms of further education and work being shaped by a number of processes and within the contexts of policy.
The current paper focuses on individual transition processes and outcomes, which pertain to microlevel phenomena that include the transition from secondary schooling to further study, as well as working and gaining experience from career education and guidance ([16]; p. 292). In addition, this ecological approach highlights the "interactive dynamics between person, process, and context over time and also in terms of its emphasis on proximal processes in driving development" ([17]; p. 60). One of the ecological systems models of development was proposed by Bronfenbrenner [18, 19], who suggested that child development is affected by experiences pertaining to each of the five interacting environmental systems, settings, or layers. McMahon et al.'s [20] Systems Theory Framework (STF), from a review and analysis of foremost literature and studies in the area, attempts to shed light on contexts and processes that entail the component of content influences comprising individual system, social system, environmental-societal system, past, present, and future; and the component of process influences consisting of recursiveness, change over time, and chance. Recursiveness refers to the connectedness within and between all elements of the system and also between systems that could address individualism and collectivism prevalent in both western and nonwestern cultures ([21]; p. 22). STF assumes that each system is open and dynamic and that they interact and interconnect with each other ([20]; p. 169).

In this light, the current study adopts the Systems Theory Framework to examine student perceptions of the school-tostudy/work transition in Hong Kong. The study is qualitative and focuses on the educational and career aspirations of Secondary 6 (equivalent to US Grade 12) senior secondary students who have recently completed their secondary education.

2.3. The New Academic Structure for Senior Secondary Education and Higher Education in Hong Kong. After a territorywide consultation, the Hong Kong government decided to implement the new academic structure which comprises a 3year senior secondary and 4-year undergraduate academic system (" $3+3+4$ ") in 2009 [22]. It means that Hong Kong strategically restructured its secondary and undergraduate education system from a British model $5+2$ (secondary and matriculation) +3 (undergraduate) to $3+3$ (junior and senior secondary) +4 (undergraduate), which is a common system in the region [23]. The new senior secondary curriculum (NSS) offers four core subjects (Chinese, English, mathematics, and liberal studies), elective subjects such as Chinese history, history, economics, and physics, and other learning experiences (OLE) [24]. At the same time, this new system provides a new and more comprehensive assessment system leading to a single diploma, known as the Hong Kong Diploma of Secondary Education (HKDSE) to replace two public examinations: the HKCEE and HKALE [22]. As pointed out by the government, "with the first administration of the HKDSE Examination in 2012, there was a considerable increase in the number of secondary school graduates qualifying for university, that is, 26,515 HKDSE 
day-school candidates in 2012 compared with 18,302 from the HKALE in that year". The proportion of HKDSE candidates qualifying for university has subsequently increased from $38 \%$ in 2012 to $40 \%$ in 2015 [24]. The demand for admission to university has been significantly increased.

Unlike universities in East and Southeast Asia witnessing a "massification" of higher education, the Hong Kong government has set around a $20 \%$ cap for the annual cohort of secondary school graduates for admission to the eight publicly funded universities [25]. To address this issue, one key aim of this NSS education is to "provide a curriculum that enables students to pursue academic and vocational/ profession education and training with articulation to a wide range of postsecondary and university education or to enter the workplace" [22].

\subsection{Educational and Career Aspirations of Senior Secondary} Student Graduates. The Hong Kong government allows private universities, community colleges, and postsecondary institutions to operate self-financing postsecondary programmes by charging students relatively high tuition fees. The number of full-time enrolments of these self-financed programmes increased from 43,216 in 2006-2007 to 76,732 in 2015-2016 [26] and keeps over 70,000 from the year of 2012-2013 to 2018-2019, which is three times that of the fulltime enrolments of publicly funded programmes [27]. The types of these self-financing programmes are quite diverse, including subdegree career-oriented higher diploma (HD) and associate degree, top-up degree, and bachelor's degree programmes. Oleksiyenko et al. [23] concluded that with such articulation pathways, Hong Kong improved access to higher education from 19 percent of the tertiary school-age population in 2000 to 60 percent in 2006 . The government notices that "due to the continued perception that university entry is a key indicator for measuring students' success," which has been considered as the main source of pressure on secondary students, and suggests that "it takes time for society to value the other pathways for students to achieve their learning and career goals, including the value and importance of vocational education" [24]. Thus, the government has encouraged schools to launch Career and Life Planning Education (CLPE) to help students "understand their own career/academic aspirations" and empower them "to make informed and responsible choices on their learning, career goals, and other aspects leading to a meaningful life" [28].

Only a few qualitative studies have explored the educational and career aspirations of senior secondary students and their educational or career destinations during their transition from secondary school graduation to further study or work. When the concept of career-related experiences was included in the education reform agenda [29], preparation for school-to-work transition from the school environment was finally able to be further enhanced in Hong Kong because a considerable number of students had failed to facilitate their study and work aspirations [30] until career- and life-planning education was formally implemented in 2014. Pavlova [31] explored aspirations and realities of
Hong Kong students and identified a number of challenges for Hong Kong youth and the government. In this light, the current study aims to examine adolescents' perceptions and outlooks related to their academic and career aspirations, as well as the support they have received from career- and lifeplanning education. The gap that this qualitative study fills involves exploring factors from different levels of a system's perspective that affect the aspirations and destinations of students.

\section{Research Methods and Data Analysis}

The current paper uses data from a project which was part of an international study of Secondary 4 (10th Grade) students in 15 cities [32]. In the first phase of the ISCY-Hong Kong study, over 5,000 senior secondary students from more than 50 secondary schools in Hong Kong participated in the survey. In the second phase, teacher and student focus group interviews were conducted in 10 schools [33-37]. Each school was requested to recommend two to three students for focus group interviews with diverse learning and life experience. A total of 26 students were interviewed. In the focus groups, participants voluntarily provided written consent and cell phone numbers for follow-up study. Interviews took place around January and February 2015. In the third phase, seven out of these 26 students from three schools voluntarily joined follow-up individual interviews conducted from August to December 2015 due to the fact that HKDSE results were not released until academic and career decisions were ascertained from the announcement of the main round of results from the Joint University Programmes Admissions System (JUPAS).

A team of university student helpers contacted survey participants through an instant messaging app-a mode of data collection which has been supported by empirical findings [38]. Such a mode of data collection was used in the current study due to the fact that student respondents in Hong Kong tend not to respond to emails or direct phone calls [39]. In the chats, the purpose of the research was explained and participants were ensured of the confidentiality of their identities. In addition to basic questions which had been asked previously in the focus group interviews, other questions were asked to probe students' academic and career aspirations and destinations as well as their initial thoughts about future pathways. Interviews in the second and third phases were conducted with the guidance of an interview guide. The main interview questions during the focus group and individual interviews reported in this study included "What are your original intentions and final decisions concerning further study or work?" "What issues would you consider, and what factors would influence final decisions regarding study or work, as well as how you make your decisions?"

This paper reports the responses of seven student interviewees from three schools with varying intakes of student according to a student's allocation band under the "Secondary School Places Allocation System" [5] in Hong Kong [33-37]. The focus group and individual interview data of these students were transcribed verbatim, after which 
the data were analyzed based on related categories of systems theory of career development ([20, 40]; p. 170). An instrument based on the Systems Theory Framework of career development was used in the Hong Kong study, suggesting that the adaptation of the framework is relevant to and usable in the local context [41].

\subsection{Background of the Participating Schools and Students.} Seven students from three schools were selected in third phase of this study. These three schools broadly represented three categories of secondary schools in terms of student profile (allocation bands) and history of the school ([34, 37, 42]). Pseudonyms have been used to protect students' privacy, with anonyms used to reflect participants' different schools, for example, Au and Aw are from School A.

School A is a renowned secondary school with a long history and intake of students with good academic results in the Hong Kong urban area. The school puts a lot of effort into empowering student leadership and attempting to tap students' potential in different ways: through academic study, sports, and extracurricular activities. According to the school's HKDSE results in 2014-2015, more than $60 \%$ of Secondary 6 students from the school gained admission into programmes at Hong Kong's top three universities, namely, the University of Hong Kong (HKU), the Chinese University of Hong Kong (CUHK), and the Hong Kong University of Science and Technology (HKUST) [Note 1]. A wide spectrum of activities in School A was available for career- and life-planning education, with, for example, talks being delivered by alumni with different professional expertise and backgrounds. A job-shadowing programme was conducted, which provided opportunities for around 100 students to engage in different companies for 1-3 days during the summer recess. In the current study, follow-ups were conducted with two students from School A-Au and Aw.

$\mathrm{Au}$ aspired to study business, as he aimed to become an investment banker or a manager in a company. He did not have a special interest in any specific university programme as long as future job prospects and salary were sufficient to sustain a good standard of living. He eventually decided to study insurance and actuarial science at one of the top three local universities on the basis of very good HKDSE results.

Aw's academic and career aspirations were to pursue a medical-related programme partly because of his personal interest and attraction to the stable and comparatively high income of the medical profession. His parents, however, had reservations about this choice because they regarded the medical profession as high-risk [43-45]. Aw obtained excellent HKDSE results and decided after all to enroll in the medical programme at one of the top three local universities after obtaining his parents' permission.

School B is a religious school situated in a new town in the Hong Kong countryside. The school puts a strong emphasis on students' holistic development, with more than $90 \%$ of students at the school obtaining passing grade Level 2 or above on elective subjects in the HKDSE public examination in 2014-2015. The school organized assembly talks for junior secondary forms (Grades 7-9) by alumni or external experts. Secondary 4 students were guided to explore their interests and to visit postsecondary institutions and firms to become familiar with different study and work pathways. For example, visits to universities in Taiwan for exploring study opportunities overseas were arranged for Secondary 45 students while aptitude tests, interviews, and decisionmaking skills training workshops were organized for senior secondary (Grades 11-12) students. Three students (Bau, Bong, and $\mathrm{Bu}$ ) participated in the current study.

Bau's academic and career aspirations were to further study and work in the Hong Kong Correctional Services Department partly because she was attracted to the income and prospects of working as a civil servant. A school teacher had previously advised her to consider enrolling on a Vocational Training Council (VTC) programme, but she felt that she would not be able to meet the entry requirements. As she did not obtain satisfactory results in the HKDSE, she decided to take up Correctional Services Studies in the Yi Jin Diploma programme and then to apply for the post of Junior Correctional Services Officer after graduation [Note 2].

Bong was interested in science subjects and aspired to study science and engineering. After the HKDSE, following advice from his family, friends, and teachers, he chose to enroll in a Higher Diploma programme in civil engineering offered by the VTC. Given the promising increase in local construction projects, this programme met his personal interests and job prospects.

$\mathrm{Bu}$ was a student with no specific academic and career aspirations because she did not have a good academic track record in secondary school. With the encouragement of her family members, she joined The Earn and Learn Pilot Scheme for Retail Industry which is a tripartite collaborative endeavour between the government, Hong Kong Retail Management Association (RMA), and the Vocational Training Council (VTC) (retrieved August 3, 2019 from http://www.vtc.edu.hk/textonly/en/about/press_4204.html). This scheme provides students with an opportunity to study a Diploma of Foundation Studies in Retail for three days at the Hong Kong Institute of Vocational Education (IVE) and acquire work experience with employers for another three days per week at retail outlets of participating companies. Apart from this, participants will also be guaranteed the employer's remuneration of an average of $\mathrm{HK} \$ 4,800$ per month and the Government allowance of an average of $\mathrm{HK} \$ 2,000$ per month, making the average monthly income to $\mathrm{HK} \$ 6,800$ (approximately US\$1,000). Given that Bu had no previous work experience, this innovative scheme would enable her to develop (vocational skills) and earn at the same time (retrieved August 3, 2019 from https://www.hkrma.org/ en/development/earn_learn_foundi.php and http://www. vtc.edu.hk/html/en/about/press_3089.html).

School C was originally a prevocational school, also situated in a new town in the Hong Kong countryside, and subsequently converted to a mainstream school. The school focused on students' holistic development. Public examination results revealed that about $25 \%$ of students enrolled in local and overseas university programmes, another $25 \%$ students were able to study in local full-time postsecondary 
or vocational training programmes, and $30 \%$ of students decided to go directly out to work. The school arranged various career- and life-planning education activities, such as job-shadowing programmes, interview training, university mock interview sessions, and study tours to the Mainland and to Taiwan universities. Two students (Chan and Cheng) were involved in different phases of the current study.

Chan's academic aspiration was to enroll in a programme in leisure and recreation because of his personal interests and achievements in physical education. He saw his future profession as becoming a coach or physical education teacher. His mother, however, was against this choice and wished him to become a plumber or an electrician, on the basis that physical education job prospects were not very promising. Given the significant recognition Chan had obtained, he finally chose to study an Associate Degree (AD) in Physical Education. However, at the orientation camp, he was impressed by peers who were looking to study social work. As a result, he decided to pursue the AD programme but would retake HKDSE for applying a social work programme in the future.

Cheng's academic aspiration was to enroll in an arts, fine arts, or translation-related programme, and her parents, school teachers, and friends encouraged her to pursue further studies after graduating from secondary school. She did not, however, feel much sense of urgency or have high expectations in terms of her studies because she did not expect good results in the HKDSE. And indeed, on obtaining poor HKDSE results, Cheng decided to go out to work and took up a part-time job in a convenience store.

3.2. Data Analysis. A coding scheme based on the Systems Theory Framework of career development was designed to analyze the content and process influences that affect the perceptions of aspirations and destinations of students of their work or study after senior secondary school (see Table 1).

The System Theory Framework functioned as a guiding framework for analysis, and the reported themes were through a process of comparing and contrasting of the nodes in Nvivo of the generated quotes. Two researchers crosschecked the findings to ensure accuracy; using Cohen's kappa, the intercoder agreement was 0.72 , which indicated high intercoder reliability (see [46] [Note 3].

Notably, most participants primarily aspired to pursue further studies when they were first interviewed around January and February 2015 before taking the HKDSE examination in April and prior to completion of their secondary education. The data collected therefore quite accurately reflected the initial or premature stage of the majority of students' career assessments.

\section{Findings and Discussion}

Four major themes emerged from an analysis of the data in the current study. They are as follows:

(1) The majority of participating students preferred undergraduate to higher diploma, associate degree programmes, or courses organized by VTC and other postsecondary institutions, unless they anticipated poor performance in the HKDSE. Seeking employment immediately after graduation from secondary school might not be a common choice.

(2) Students understand that the HKDSE result is a key factor in determining their choices and educational and career aspirations.

(3) The educational and career aspirations and destinations of students were influenced by their parents and family members, whereas other students considered the advice of teachers, social workers, classmates, and friends.

(4) Students' career aspirations were related to their personal interests, job prospects, and stability of the job or profession.

The result of mapping the reported themes onto content and process influences in the coding scheme demonstrated good alignment. With reference to Table 1, theme 1 includes the environmental-societal system; theme 2 includes change over time; theme 3 includes the social system and process influences; and theme 4 includes past, present, and future. These themes were found to be unique as they elaborated views of students on academic and career aspiration and destinations from times which they made the decision on from transition to further study or work. The following findings show selected typical comments expressed by student interviewees under the four themes.

4.1. Educational Aspirations That Favour University Education over a Higher Diploma, Associate Degree, or Immediately Joining the Workforce. Several students aspired to pursue undergraduate study at university, HKDSE results permitting. Pursuing employment immediately after graduation from secondary school received a much lower priority.

It is too early to work after secondary school education, I would prefer to wait before going out to work after gaining more insights from university. (Au)

I originally wanted to study physical education $(P E)$ in the VTC. I did not perform well enough in the public exam, so I can only study in a postsecondary college. At the very beginning, I wished to study a degree in PE at the Hong Kong Institute of Education (HKIEd). (Chan)

Such comments, together with the results of the previous ISCY-HK survey [47], indicate that senior secondary students preferred to enroll on a bachelor degree programme at university over higher diploma, subdegree studies, or seeking employment. Additionally, compared with their counterparts in Australia, senior secondary students in Hong Kong did not expect to work right after graduation from secondary school [1]. Seeking employment immediately after graduation from secondary school might not be a common choice because both parents and students believed that pursuing university or postsecondary education would 
TABLE 1: Coding scheme based on the Systems Theory Framework of career development [20].

\begin{tabular}{|c|c|c|}
\hline $\begin{array}{l}\text { Content and process } \\
\text { influences under a } \\
\text { systems theory } \\
\text { framework }\end{array}$ & $\begin{array}{l}\text { Factors affecting the } \\
\text { destination of study or work }\end{array}$ & Examples of quotations by interviewee (name/school) \\
\hline \multicolumn{3}{|l|}{ Content influences } \\
\hline \multirow{3}{*}{ Individual system } & $\begin{array}{l}\text { Personal interest towards a } \\
\text { specific discipline/ } \\
\text { programme }\end{array}$ & $\begin{array}{l}\text { I select diploma of PE as I have strong interest since F.1, and I can foresee the } \\
\text { prospect of studying PE until F.6. Becoming part of the Hong Kong national } \\
\text { team would not be the only best way to accomplish a good prospect. } \\
\text { Therefore, I can become neither a PE teacher nor a recreational-related } \\
\text { practitioner. (Chan) }\end{array}$ \\
\hline & $\begin{array}{l}\text { Personal interest towards a } \\
\text { specific occupation }\end{array}$ & $\begin{array}{c}\text { (Studying engineering is because) I want to design a building, and my work } \\
\text { aspiration is to become an engineer. (Bong) }\end{array}$ \\
\hline & $\begin{array}{l}\text { No specific interest or } \\
\text { aspiration }\end{array}$ & $\begin{array}{l}\text { I have no specific dream, as my sister advised me to select correctional } \\
\text { service. In my view, I just want to be assured I would be a civil servant. (Bau) }\end{array}$ \\
\hline \multirow{3}{*}{ Social system } & $\begin{array}{l}\text { Family reasons/parental } \\
\text { advice }\end{array}$ & $\begin{array}{l}\text { Family members recommended me to study in the Earn and Learn Pilot } \\
\text { Scheme, so I joined it. }(\mathrm{Bu})\end{array}$ \\
\hline & Peers/alumni/friends' advice & $\begin{array}{l}\text { My family and friends affect my decisions the most. I will discuss with them } \\
\text { then and think for myself if I need to make serious decisions. ( } \mathrm{Au} \text { ) }\end{array}$ \\
\hline & $\begin{array}{l}\text { Teachers/social workers' } \\
\text { advice }\end{array}$ & $\begin{array}{l}\text { I want to study Social Work now. From my experience at orientation camp, I } \\
\text { was advised to have some personal problems and propose to make some self- } \\
\text { improvements. My study in Social Work is to figure out the problem and } \\
\text { improve it. (Chan) }\end{array}$ \\
\hline
\end{tabular}

\begin{tabular}{c}
\hline $\begin{array}{c}\text { Societal value over people } \\
\text { with higher educational and } \\
\text { qualification }\end{array}$ \\
Environmental-
\end{tabular}

societal system

Admission requirements of a specific programme

Prospect of an occupation and future pathways

Past, present, and future

Future salary and job security
It is too early to work after secondary school education, I would prefer going for work after gaining more insights from university. (Au)

Probably, I expect my DSE results are not good, also I do not know what I can do. Hence, my parents help me explore this scheme. I found this scheme is what I am looking for since I have no working experiences, I could gradually gain from it and change myself. (Bu)

(I prefer studying engineering) because it has better job prospect, I love engineering and nursing. (Bong)

I have no special job preference. My key goal is to earn a living, and being a managerial staff can have greater salary. I would let it be if there would get changes later on. $(\mathrm{Au})$

Process influences

Career- and Life-Planning Education (CLPE) support at school

Recursiveness, change

Public examination (HKDSE) results

over time, chance
There is a mock release of DSE results, and we role play on job hunting and searching appropriate programmes. I deem this programme as good. Several guests come from VTC, which I feel useful. (Bau)

From certain activities, I could know more about how to communicate with the police and the job duty of disciplined service. I like nursing during my secondary study. Although I feel interested in these three aspects, my decision would still depend on my DSE results. ... I prefer studying Nursing, but I cannot meet the entry requirement, thus I finally studied foundation diploma. (Bong)

I want to work rather than further study ... nevertheless I think I deserve to join this programme, as tuition fee is reasonable and affordable, and I can also go to work. I decided to study this programme because I think it can help my career development, and the low tuition fee is affordable. $(\mathrm{Bu})$

Cost of specific programme

highly valued ([48]; pp. 84-85). In addition, social expectations were found among students who perform well in public examinations; these students enrolled in competitive programmes, such as medicine, law, and global finance-subjects that require top HKDSE scores. toriously intense" ([23]; p, 33). And it is a common pattern in Hong Kong that "[h]ighly educated families often act rationally to position their children for progress from reputable schools to analogous university programmes" (p. 34).

These results echo those obtained from a cultural perspective that education, which is an important means of social mobility in a Chinese society such as Hong Kong, is
4.2. Academic Aspirations Coupled with HKDSE Results. Many students highlighted the fact that unsatisfactory HKDSE results inhibited their choice of articulation pathway to postsecondary studies which lead to different 
qualifications and status. On the contrary, Yuen and Yau [49] pointed out that most schools in Hong Kong are placing more emphasis on students' performance in public examination, rather than providing career guidance and counselling to develop students' career adaptabilities. And this may explain why "many parents in Hong Kong prefer that their children concentrate on gaining a place for further education upon graduation, instead of engaging too early in career exploration" (p. 154).

As I only got level 1 in English language, I could only work part-time and study part-time....I understand qualifications are crucial, so I would prefer to study for some more years and then work several years more. (Bau)

Not every student is able to obtain good results in the HKDSE examination given the competitiveness of the education system in Hong Kong. Yi Jin and VTC programmes, which charge relatively low fees compared with other selffinancing programmes, have become alternatives for students who fail to obtain satisfactory HKDSE results, as well as those who encounter financial hardships.

As my HKDSE results only allow me to study a foundational diploma, this [VTC] programme is a good fit for me well because I only need to work three days and study three days a week, and the tuition fee is reasonable and affordable. I think it is good for me to "earn and study" at the same time. I feel my time will not be wasted, and I can learn some skills and gain some working experience. (Bu)

Some students were concerned about the value of an associate degree and the possibility of subsequent articulation to a degree programme.

It is time to avoid any further expansion of associate degree programmes, otherwise this will only produce qualification inflation and employment delay. It is understood that job prospects are highly correlated with your ability, and ability must be proven by final outcome (performance). So, it's better to gain more work experience - for better personal growth. Many also feel that articulation to an undergraduate degree from an associate degree programme is very uncertain, so maybe we should consider getting rid of associate degree programmes. (Aw).

I want to work rather than continue studying ... nevertheless, I think I deserve to join this (associate degree) programme, because I think it can help my career development. (Bu)

These results echo one of the key findings of Mourshed, Farrell, and Barton's [50] report "70 percent of young people surveyed believe vocational schools are more helpful in getting a job and half said they find it more appealing than an academic track [...] nearly two-thirds of youth said that vocational tracks were less valued by society" (p. 31). Academic aspirations are more than career choice and planning. Tuijnman [51] maintained that a students' life planning and career choice should be built on the economic, social, political, and cultural heritages of a particular community.

\subsection{Parental and Family Influences and Support as Key Sources} of Influence in a Social System. Parents are important sources or people who affect the educational and career aspirations of students, as shown by the following comments:

I have no specific dream; it has been my sister who advised me to select the discipline forces (correctional services). (Bau)

It was my family members who suggested that I study in the Earn and Learn Pilot Scheme. (Bu)

Chan's parents did not support his choice of becoming a coach or PE teacher because perceived job prospects were not very promising. Nevertheless, given his achievements in $\mathrm{PE}$ and after convincing his parents, he finally enrolled in an Associate Degree in PE.

(My parents would prefer me to become a plumber as they feel that studying sports does not have very good prospects). (Chan)

Although many studies suggested parental encouragement has a positive effect on students' motivation, academic achievement, and educational aspirations [52-54], parents may not always support their children's choices. This may simply be because of parents' perceptions about certain professions. Aw commented that

My parents normally would not interfere with my decision because my academic results have been good. They had not asked too much ....... [However,] my parents do not support my decision to study medicine. They are afraid I will face different high risks, such as another outbreak of SARS, and that I would have to be the first one to tackle it. (Aw)

Students' final decisions and educational destinations are not always static but in flux with their personal interests, their job prospects, and their HKDSE results. Students should be able to comprehend and analyze the individual and familial constraints in education and career choices [55]. At the same time, students ought to understand the opportunities and limitations of each, so as to be emotionally well prepared for facing any positive or negative changes in the future. For instance, despite his parents' concerns over his choice, Aw decided to press ahead with his wish to study medicine because of his personal interests, the job stability inherent in being a doctor, and his own outstanding HKDSE results.

Teachers, classmates, and friends also proffer advice that at times shape students' educational and career aspirations, although their comments often tend to be perceived as unrealistic or impractical. As Bau comments 
My school teacher suggested that I go to study at the VTC, but I do not think I can graduate there because I would fail the TOEIC test (Test of English for International Communication). I can feel that they only casually recommended an option for me. (Bau)

On understanding and exploration of educational and career aspirations, students in their individuality should be empowered to work out a clear and rational link between choices and individuality and manage their own personal goals with the environmental change of fast-changing economic landscape [56, 57]. Different generic skills, especially in terms of managing the decision-making and problem-solving processes, ought to be reinforced by their parents and teachers, which help shaping students' future attitudes towards lifelong learning [58]. Such understanding and exploration demand at the same time a high level of selfawareness, in which knowledge of internal milieu is a defined entity that acts on the world and experience it across time and space [59].

4.4. Academic and Career Aspirations to Be Shaped by Personal Interests, Ability, Job Stability, and Prospects. Many students placed a higher priority on stability and on the prospects offered by the job or profession since these would affect their career and educational aspirations retrospectively.

My study decisions are based on how a career can sustain my daily life. Given that I need job stability, I would think about if there is possibly going to great changes or demands in this industry, otherwise I am afraid I cannot have job security. ... My key goal is to earn a living and being a manager means a better salary. If there is no major change in the nature in the industry, I will then be able to just live my life as a manager. (Au)

I am only considering prospects and salary in my considerations about studying correctional services. (Bau)

Several students emphasized that their educational and career aspirations depended on their own interests and their own ability. They were very determined to aspire to a desired destination once they could make up their minds and have a clear direction for their future path.

(I want to study engineering because) I want to design a building, and my work aspiration is to become an engineer. (Bong)

My decision to work is based on my own personal intentions. My parents urged me to continue my studies, but have finally agreed to my decision, as I have a clear mind about my future path. (Cheng)

Many students attempted to strike a balance between their personal interests and perceived stability, and specific job or profession prospects in formulating their educational and career aspirations. Their behavior can be explained by
Eccles and Wigfield's [60] notion regarding the distinction between situational and individual interests where the former refers to the state of preference aroused by the specific features of a given task or activity, while the latter refers to a relatively stable orientation towards related tasks or activities.

I have been considering a number of factors, and job stability is the first factor because it helps me get married easily. Personal interests are the second factor, and the last factor is the learning experiences I will get during my university life. (Aw)

I have had a strong interest in PE since Form 1 (Grade 7), and I can foresee good prospect of studying PE until Form 6 (Grade 12). Becoming part of the Hong Kong national team, [I realized it] is not the only good route to good prospects. Therefore, I am selecting Associate Degree in PE so that I can become either PE teacher or a recreationalrelated practitioner. (Chan)

Making decisions about further study and work after senior secondary schooling is an important stage for students, especially in exploring career interest and socializing into adulthood. As informed by Illeris [61], learning during this stage demands a student's rapid identity development of who he or she is as restructuring learning (vis-à-vis additive learning) occurs more and more frequently. If advancement embraces external ambitions and internal motivation, then goal setting and goal achieving for academic and career aspirations are indispensable. Making wise choices and the associated decisions is one important aspect of goal setting and goal achieving, and solving the problem raised and adjusting the path in the process is another. Students ought to acquire the ability to coordinate long-term goals with the possibility of change in the future.

4.5. Comparison between Students' Academic and Career Aspirations and Their Destinations. Table 2 presents a composite picture of participants' academic and career aspirations and destinations.

As can be seen from Table 2, the majority of students in the current study aimed to pursue further studies, with the majority succeeding in this aim. Their aspirations were restricted to a choice between study and work, with students lacking the imagination to think about more diversified school-to-work transition pathways.

Qualifications are crucial, so I would prefer to study for some more years and then work. I will only go out to work if I cannot further my studies. (Bau)

Several students stressed how they felt unable to really pinpoint where their personal interests lay. Concerning career aspirations, for example, some stated that they would initially consider a job if it appeared to have good future prospects and salary sufficient to sustain a good standard of living. Parental advice remained crucial in this decisionmaking area. 
TABLe 2: Academic and career aspirations and destinations of students (during the period of study).

\begin{tabular}{|c|c|c|c|c|c|}
\hline Name & $\begin{array}{c}\text { Educational aspirations } \\
\text { (old/new) }\end{array}$ & $\begin{array}{l}\text { Career aspirations } \\
(\text { old/new })\end{array}$ & Educational destinations & Career destinations & $\begin{array}{l}\text { Major influences on } \\
\text { change (if applicable) }\end{array}$ \\
\hline $\mathrm{Au}$ & Business & Investment banker & $\begin{array}{l}\text { Insurance and actuarial } \\
\text { analysis program (local } \\
\text { publicly funded } \\
\text { university) }\end{array}$ & N/A & $\begin{array}{c}\text { Personal interest, } \\
\text { parental and peer } \\
\text { influences, and future } \\
\text { salary }\end{array}$ \\
\hline Aw & $\begin{array}{l}\text { Medical-related } \\
\text { programme }\end{array}$ & Medical professional & $\begin{array}{c}\text { Medicine programme } \\
\text { (local publicly-funded } \\
\text { university) }\end{array}$ & N/A & $\begin{array}{c}\text { Personal interest and } \\
\text { parental influence; job } \\
\text { security }\end{array}$ \\
\hline $\mathrm{Bau}$ & Unclear & $\begin{array}{c}\text { Civil servant } \\
\text { (Correctional Services } \\
\text { Officer) }\end{array}$ & $\begin{array}{c}\text { Yi Jin programme } \\
\text { (in a privately funded } \\
\text { institution) }\end{array}$ & N/A & $\begin{array}{c}\text { Family (sister's) } \\
\text { influence; job security }\end{array}$ \\
\hline Bong & Civil engineering & $\begin{array}{l}\text { Engineer, medical care } \\
\text { officer, and police officer } \\
\text { (depending on HKDSE } \\
\text { results) }\end{array}$ & $\begin{array}{l}\text { Foundation Diploma } \\
\text { programme } \\
\text { (in a privately-funded } \\
\text { institution) }\end{array}$ & N/A & $\begin{array}{c}\text { Parental influence, } \\
\text { personal interest, and } \\
\text { teacher and peer } \\
\text { influences; future salary }\end{array}$ \\
\hline $\mathrm{Bu}$ & $\begin{array}{l}\text { The Earn and Learn Pilot } \\
\text { Scheme for retail industry }\end{array}$ & $\begin{array}{l}\text { A worker in a retail } \\
\text { company/industry }\end{array}$ & $\begin{array}{l}\text { A programme under the } \\
\text { Earn and Learn Pilot } \\
\text { Scheme (offered by a } \\
\text { privately funded } \\
\text { institution) }\end{array}$ & $\begin{array}{l}\text { Part-time study } \\
\text { and part-time work }\end{array}$ & $\begin{array}{c}\text { Parental and peer } \\
\text { influences and personal } \\
\text { interest }\end{array}$ \\
\hline Chan & Recreation and leisure & $\begin{array}{c}\text { Coach/physical education } \\
\text { teacher }\end{array}$ & $\begin{array}{l}\text { Associate Degree in } \\
\text { Physical Education } \\
\text { (in a privately funded } \\
\text { institution) }\end{array}$ & $\mathrm{N} / \mathrm{A}$ & $\begin{array}{l}\text { Personal interest and } \\
\text { parental influence }\end{array}$ \\
\hline Cheng & $\begin{array}{l}\text { A programme related to } \\
\text { arts, translation, and fine } \\
\text { arts }\end{array}$ & Translation or art related & $\mathrm{N} / \mathrm{A}$ & $\begin{array}{l}\text { Part-time worker } \\
\text { in a convenient } \\
\text { store }\end{array}$ & $\begin{array}{l}\text { Academic performance; } \\
\text { personal interest }\end{array}$ \\
\hline
\end{tabular}

N/A: nonapplicable.

My main considerations are whether my future salary can support my daily life. As for my interests, I am not really clear about my own interests at this point in time. (Au)

As I don't really know what I want to do, I've been asking my mother for information. Sometimes I ask my friends for their opinions and suggestions about my plans, although most of the time I ask my mother because she is more experienced when it comes to work. (Bu)

Some students, those with a strong sense of determination, had a clearer sense of direction. Self-understanding is significant for personal work and study aspirations, and it helps students make the transition from their own situation during their real work experiences and then devise plans as to what they might need to follow up on.

I have heard that being a doctor means having a busy life. I am happy to have a busy life although I am not sure if this means it is going to enjoyable. I guess I will find out more when I eventually become a doctor. (Aw)

I know I want to go to work right now, and I know I don't have much chance of further studies at university because I am not very good at studying.... I think it is important to get a taste of the workplace though and build up my communication skills, so I will try and get a job. (Cheng)
One student remarked very perceptively that the temporary postsecondary destination could only be further studies, which is the hidden social norm. Higher qualifications indicate higher personal competitiveness in terms of being successful in society. Society, along with parents, did not provide students with sufficient support to achieve personal interests in a work destination.

My first choice after the HKDSE would be to study because in Hong Kong, if you do not have certain qualifications, you are less recognized in society. So, it is better to work with qualifications. Although starting work earlier can give me a range of experiences, those experiences may not be that highly valued in this society. If you can live to 80 , and you spend your first 18 years studying, you still have another 62 years when you have to work. So, it is better to study first as I'll get nothing at 18. (Chan)

4.6. Career-and Life-Planning Education (CLPE) Support (as a Process Influence). CLPE was seen to facilitate students' academic and career planning. CLPE activities, such as teacher advice, small group discussions and workshops, as well as learning through attachment, job shadowing, and alumni sharing, were all perceived as useful. Some activities, however, were seen as only catering to high performers.

Career teachers contacted different alumni to try and answer some of our queries. If we had difficulties, we could 
ask them as well. Our school provides us with the opportunity to get to know some in-service doctors through joining the attachment programme. I could do some job shadowing to get some real work experience. (Aw)

Everyone deserves a meaningful life, and middle-to-low level students should not be ruled out. So, it would be a good idea to invite some middle-to-low performers to share their experiences. (Bau)

I joined such seminars before, but I went to sleep. Such activities tend to be targeted at students who are good academically, and middle-to-low performing students are ignored. (Chan)

A number of students felt that CLPE activities and supports were not very effective in helping them shape their aspirations and future plans.

Alumni sharing is a nice idea, but it didn't really help me much. (Bong)

(The school support) is good, but usually it is just all seminars and talks. The content is mainly about past experiences or current situations, which does not apply to my case. They talk about JUPAS requirements, for example, but I have no chance of getting into university, so such talks are a waste of time for me. (Bu)

These students expressed views on how CLPE might be improved. They suggested that career counselling and social work support could be provided before and after the release of the HKDSE examination results, especially for students who were marginal cases. Furthermore, increased attention could be put on low-performing students, provide them with practical skills, such as writing application letters.

Seminar talks are arranged badly. It is meaningless to get the best performing VTC student, who can no doubt be offered a place at university to talk to us. It would be better if they invited some middle-to-low students to talk. (Bau)

The workshops organized by the social worker were helpful for those who are in middle-to-low achievers, so they could consult then social workers for advice on what to do. (Chan)

The school arranged mock interviews, and the teacher consulted and commented on my draft career plans. The activities didn't include a session on teaching job application skills, though and so I didn't think the sessions were very effective. (Bong)

CLPE is an individual developmental behavior; it includes the continuous efforts of planners, teachers and coaches, parents, companies, and the community [62]. Hellevik [63] found planning is particularly important for people living in less-favorable societal conditions and needing more control because their future is considered to be less secure or stable. Thus, CLPE is become increasingly critical for the next generation. Oechsle [64] provide a concise explanation for career and life planning that it:
"Life planning is more than simply drawing up a 'blueprint' of one's life; it is a feat of social construction, involving integration into - or withdrawal from - institutions, the coordination of a functioning everyday life with others, and/or the achievement of 'idiosyncratic' life goals. As such, life planning relates to both 'standard' and 'nonstandard' occupational time structures, as well as to the life goals of significant others." (p. 85)

\section{Implications}

A systems theory framework perspective of CLPE has a number of implications for the environmental-societal system (which includes the educational system), the family system (parents), and the school system (the school's CLPE support as process intervention and influence). All these elements are part of the larger social system and impact on the individual system.

5.1. "Deferred" Transition from Education to Work at the Societal Level (System). From a systems perspective, the expansion of tertiary education and the advocacy of continuing education after secondary schooling have resulted in a somewhat deferred transition from education to work. The findings from the current study suggest that Hong Kong, as a credential-focused and competitive society, generally drives students and pushes parents to advise their children to pursue higher qualifications, preferably a bachelor degree programme in a reputable, publicly-funded university. They assume that with these higher qualifications students upon graduation will have better chance of finding more decent jobs or joining reputable professions with good salary. If students do not do well in the HKDSE, they are expected to study an associate degree or higher diploma, which will hopefully later articulate to the senior year of degree programmes or provide access to jobs with stability and prospects. For most parents and students, immediate fulltime or part-time work is considered the last resort. As suggested by Bowman et al. [65], some students such as Au and Aw, who obtained good-to-outstanding HKDSE results that would permit them to create their own "choice biographies" while other students, such as Bau and Cheng, could only expect to have limited control over their "destinies" (p. 16). Such a situation tends to be more prevalent in secondary schools which admit a high proportion of academically less able students. From a deficit perspective, the apparent lack of educational credentials is seen as the fault or responsibility of individuals (p. 16) which gives students who performed poorly in the HKDSE a sense of failure in life.

5.2. Parental Education and Engagement. The findings showed that parents remain an important source of influence on educational and career aspirations of students. According to a Systems Theory perspective, family system affects the values orientation of students, as well as their aspirations and decision-making. This finding is particularly applicable in Asian or Chinese culture societies where 
parental expectations are associated with "traditional cultural values such as filial piety, loyalty to family, and obedience to parents" ([66]; p. 350). However, depending on parental background, knowledge of the changing economy, labour market, and attitudes toward different professions, parental expectations could facilitate or bolster the decisionmaking and choice of their children. Therefore, parents should act as critical friends to listen to their children's inner voices and views, become a guardian or life coach who provide advice and guidance, and introduce intervention to facilitate informed decisions of children. At the school level, instead of a "band-aid model" of parental engagement, "a strengths-based model should be adopted which would seek to fully harness the talents, knowledge, and experience of parents, whereby they have the opportunity to contribute not only to the career development of their own child but also to an entire cohort of similarly placed young people" ([67]; p. 22).

5.3. Strengthening CLPE in the School System. The findings showed that CLPE activities were seen as useful and effective in general; however, several students opined that students, especially those with middle or low levels of academic attainments, deserve increased attention and support. Ho [68] argued that "[c]ompensatory resources should be allocated to the least advantaged, and their exposure should not be restricted to a few vocational choices." However, this programme needs consensual and concerted efforts from the government, schools, NGOs, and employers. In addition to tailor-made workshops, talks, internships, and individual career counselling, the government can implement Individual Student Planning (ISP) activities or programmes in secondary schools to "help students explore and develop educational and career goals" ([68]; p.135), and "assist students in understanding and periodically monitoring their career, academic, and personal/social development." (p. 121) And the major components of ISP portfolios include "understanding of self, interests, personalities, career aspirations, and aids for decision-making." ([69]; p. 198) Apart from these traditional programmes and activities, stakeholders should explore the use of social networks in strengthening CLPE in the school system. Nowadays, senior secondary students or young adults may be more receptive to these new forms of tutoring, communications, and collaboration between students and teachers ([70]; p. 168), personalized tutoring [71], social networking- (SN-) based learning systems [72], and intelligent e-learning systems [73].

\subsection{Enhancing Self-Knowledge and Career A wareness from an} Individual Perspective. Several students revealed that they might not have clear or explicit career aspirations focusing on job prospects and stability. This notion is understandable in a pragmatic and competitive society like Hong Kong, but adolescents could forge a vision for their future career linking with their meaning of life through CLPE activities. To some extent, it echoes the findings of a study conducted in Hong Kong that there were "strong association between career concern and presence of meaning in life." On the other hand, it is noted that "schools are still placing higher emphasis on the academic attainment of students in examinations, rather than enriching their career readiness opportunities" ([49]; p. 154).

\subsection{Facilitating Transitions for Students from Education to} Work through Multiple Pathways. To ensure a smooth transition for students, interested parties and stakeholders should assume responsibility and take proactive action. Multiple pathways for second-chance learning after secondary schools should be implemented for students who could not perform well in the HKDSE examination. Suggestions were offered on the level, focus, and nature of intervention. Bowman et al. [65] provide a summary of common approaches could be considered according to their focus and intent. At the individual level, financial incentives and subsidies could be provided to encourage students studying programmes and courses with individual support, parental engagement, and career guidance. Vocational education and training could encompass an alternative learning environment, which is different from the traditional schooling and college learning experiences. Other measures to foster employability of these young people include apprenticeships and dual training education, internships, and work experiences that highlight generic skills development (p. 25).

\section{Concluding Remarks}

This study has been a qualitative study examining the academic and career aspirations of senior secondary students with a focus on "school-to-work" transition. It is acknowledged that the current study has two limitations due to the constraints of its research design. Firstly, most student interviewees were less willing to engage in face-to-face interviews, and they are not easily available and accessible for communication over a relatively long period of time before and after the completion of secondary schooling. Despite making use of WhatsApp or social media to conduct these interviews, the time, energy, and patience required for participating in this study was very demanding for them. Secondly, the sample size of twenty-six student interviewees from ten schools was small as such the qualitative findings could not be statistically generalized to a large sample. In future, a quantitative study involving a large sample should be conducted to reveal a better picture of the academic and career aspirations of senior secondary students in Hong Kong.

To conclude, underlying social norms deepened the conflict between the social system and personal will. Parental influence unavoidably shifts student interest towards academic study rather than vocational study and immediate work in the deficit school-to-work transition. The local educational system is another determining factor that reduces potential alternative pathways available for students. Subdegree programmes, such as vocational education and training (VET) programmes, are usually considered 
alternative or second choices. Therefore, the integration of CLPE into the current educational system can be considered an initial step for enhancing self-determination of the students in the transition and relieving varying sources of conflict.

\section{Data Availability}

The interview data used to support the findings of this study have not been made available because of confidentiality reasons.

\section{Additional Points}

(1) In the HKDSE, candidates' performances are reported in five levels (Level 1 to 5), with 5 being the highest. Level 5 candidates with the best performance are awarded a $5 * *$, and the next top group of candidates are awarded a $5 *$. For university admission purpose, the general entrance requirements are HKDSE minimum Level 3/2 for core subjects and Level 3 for elective subjects. Details read Joint University Programme Admissions System (JUPAS) website https:// www.jupas.edu.hk/en/. (2) Fleiss [46]; discussing levels of kappa, suggests that 0.4-0.75 indicates "good" agreement, while 0.75 or above indicates "excellent" agreement. (3) One of the objectives of the Yi Jin programme is to offer a second choice to both secondary 6 graduating students and adult learners in order to achieve academic recognition for the goals of continuous education and employment.

\section{Conflicts of Interest}

The authors declare that they have no conflicts of interest.

\section{Acknowledgments}

The authors thank the principal, teachers, and students of schools A, B, and C, as well as personnel involved in the ISCY-HK for their kind support. The authors also thank Mr. Michael Chau, Ms. Carol Tjan, Ms. Melissa Au, and Ms. Hilton Cheung for their help in preparing this manuscript. The work described in this paper was supported by a grant from the Research Grants Council of the Hong Kong Special Administrative Region, China (project no. HKIEd 843212), Centre for Excellence of Learning and Teaching, the Department of Curriculum and Instruction from the Education University of Hong Kong (formerly Hong Kong Institute of Education).

\section{References}

[1] G. N. Marks, C. Underwood, S. Rothman, and J. Brown, Career Moves: Expectations and Destinations of NSW Senior Secondary Students, Australian Council for Educational Research, Melbourne, Australia, 2011.

[2] The Social Research Centre, NSW Secondary Students' Postschool Destinations and Expectations, The Social Research Centre, Melbourne, Victoria, 2015.

[3] J. Dounay, "Embedding college readiness indicators in high school curriculum and assessments," Policy Brief. Education Commission of the States (NJ1), 2006.
[4] Task Force on Promotion of Vocational Education, Report of the Task Force on Promotion of Vocational Education, Education Bureau, Hong Kong, 2015.

[5] Education Bureau, "Information leaflet on the secondary school places allocation system 2016/2018 cycle," 2019, https:/www.edb.gov.hk/attachment/en/edu-system/primarysecondary/spa-systems/secondary-spa/general-info/Leaflet_ SSPA1618_E.pdf.

[6] M. Rogers, P. Creed, and P. A. Creed, "School-to-work transition: from theory to practice," Australian Journal of Career Development, vol. 9, no. 3, pp. 20-26, 2000.

[7] A. Bandura, Social Learning Theory, General Learning Press, NJ, USA, 1971.

[8] E. L. Herr, "Perspectives on ecological context, social policy, and career guidance," The Career Development Quarterly, vol. 45, no. 1, pp. 5-19, 1996.

[9] J. D. Krumboltz and R. L. Worthington, "The school-to-work transition from a learning theory perspective," The Career Development Quarterly, vol. 47, no. 4, pp. 312-325, 1999.

[10] A. Bandura, Social Foundations of Thought and Action: A Social Cognitive Theory, Prentice-Hall, Englewood Cliffs, NJ, USA, 1986.

[11] B. K. Bryant, A. M. Zvonkovic, and P. Reynolds, "Parenting in relation to child and adolescent vocational development," Journal of Vocational Behavior, vol. 69, no. 1, pp. 149-175, 2006.

[12] J. L. Holland, Making Vocational Choices: A Theory of Vocational Personalities and Work Environments, Psychological Assessment Resources, Odessa, FL, USA, 3rd edition, 1997.

[13] R. V. Dawis and L. Lofquist, A Psychological Theory of Work Adjustment, University of Minnesota Press, Minneapolis, MN, USA, 1984.

[14] D. E. Super, The Psychology of Careers; an Introduction to Vocational Development, Harper, New York, NY, USA, 1957.

[15] M. L. Savickas, "The transition from school to work: a developmental perspective," The Career Development Quarterly, vol. 47, no. 4, pp. 326-336, 1999.

[16] D. Raffe, "The concept of transition system," Journal of Education and Work, vol. 21, no. 4, pp. 277-296, 2008.

[17] M. O'Kane, “Building bridges: the transition from preschool to primary school for children in Ireland," Dublin Institute of Technology, Dublin, Ireland, Doctoral Dissertation, 2007.

[18] U. Bronfenbrenner, The Ecology of Human Development: Experiments by Nature and Design, Harvard University Press, Cambridge, MA, USA, 1979.

[19] U. Bronfenbrenner, "Ecological systems theory," in Six Theories of Child Development: Revised Formulations and Current Issues, R. Vasta, Ed., Jessica Kingsley Publishers, London, UK, 1992.

[20] M. McMahon, W. Patton, and M. Watson, "My system of career influences," in Career Assessment: Qualitative Approaches, M. McMahon and M. Watson, Eds., Rotterdam, The Netherlands, Sense Publishers, 2015.

[21] M. McMahon, "New trends in theory development in career psychology," in Handbook of Career Development: International Perspectives, G. Arulmani, A. J. Bakshi, F. T. L. Leong, and A. G. Watts, Eds., Springer Science + Business Media, New York, NY, USA, 2014.

[22] Education and Manpower Bureau [EMB], "The new academic structure for senior secondary education and higher education-action plan for investing in the future of Hong Kong," 2005, https://334.edb.hkedcity.net/doc/eng/report_e.pdf.

[23] A. Oleksiyenko, K. Cheng, V. Lee, and S. Tang, "University and college admission policies and practices in Hong Kong 
SAR, China: opportunities and challenges in moving from secondary education to tertiary education," France: UNESCO and UNESCO Bangkok Office, 2015, http://unesdoc.unesco. org/images/0023/002328/232851E.pdf.

[24] Curriculum Development Council [CDC], Continual Renewal from Strength to Strength, Education Bureau, Hong Kong, 2015, https://334.edb.hkedcity.net/doc/eng/MTR_Report_e.pdf.

[25] K. H. Mok, "Massive expansion of universities in Asia raises tough questions on social mobility," The Conversation, 2016, http:// theconversation.com/massive-expansion-of-universities-inasia-raises-tough-questions-on-social-mobility-54680.

[26] Information Portal for Accredited Post-Secondary Programmes (iPASS), Enrolments of Full-Time Accredited SelfFinancing Post-secondary Programmes 2006/07 to 2015/16 Academic Years, HKSAR government, 2016, http://ipass.gov. hk/edb/index.php/en/home/statheader/stat/stat_el_index.

[27] Concourse for Self-financing Post-secondary Education, Advanced Data Search: Full-Time Locally-Accredited Self-Financing Post-secondary Programmes, 2018, https://www.cspe. edu.hk/en/customised-data-retrieval.page.

[28] Career Guidance Section, School Development Division, Education Bureau, Guide on Life Planning Education and Career Guidance for Secondary Schools, Education Bureau, Hong Kong, 2014, 1st edition, https://careerguidance.edb. hkedcity.net/edb/export/sites/default/lifeplanning/.pdf/ about-careers-guidance/CLP-Guide_E_r3.pdf, 1st edition.

[29] S. Y. W. Yip, Thoughts on Career-Related Experience in the Curriculum Reform, Curriculum Development Council, Hong Kong, 2001, http://cd1.edb.hkedcity.net/cd/lwl/CRE_WEB/ file/Career\%20related.pdf.

[30] S. M. Chan, Impact of Career-Related Experiences on Career Education and Guidance at New Senior Secondary level, Master Thesis, The University of Hong Kong, Hong Kong, 2011.

[31] M. Pavlova, "Aspirations of and realities for Hong Kong students: is the "formal" transition system effective?," Educational Research for Policy and Practice, vol. 16, no. 1, pp. 77-93, 2017.

[32] International Study of City Youth (ISCY), "The S4 class of 2013: all Hong Kong schools," First ISCY Report: Results from the Student Survey, Melbourne, Australia Victoria University, 2015.

[33] J. C.-K. Lee, "Curriculum reform and supporting structures at schools: challenges for life skills planning for secondary school students in China (with particular reference to Hong Kong)," Educational Research for Policy and Practice, vol. 16, no. 1, pp. 61-75, 2017.

[34] J. C. K. Lee, N. C. Chan, H. Xu, and D. W. S. Chun, "Students' and teachers' perceptions of creativity, communication and problem-solving in the school curriculum: Hong Kong perspective," Educational Practice and Theory, vol. 39, no. 1, pp. 29-50, 2017.

[35] J. C. K. Lee and O. N. K. Ho, “Schools' support for postschool planning: a Hong Kong perspective," in Transitions to PostSchool Life: Responsiveness to Individual, Social and Economic Needs, M. Pavlova, J. C. K. Lee, and R. Maclean, Eds., Springer, Singapore, 2017.

[36] J. C.-K. Lee, E. H.-f. Law, D. W.-s. Chun, and K. N.-c. Chan, "Cultivating self-management and leadership skills among Hong Kong Students," Curriculum and Teaching, vol. 32, no. 1, pp. 5-24, 2017.

[37] H. Xu and J. C. K. Lee, "Exploring the contextual influences on adolescent career identity formation: a qualitative study of
Hong Kong secondary students," Journal of Career Development, vol. 46, no. 3, pp. 219-234, 2017.

[38] J. V. Henry, N. Winters, A. Lakati et al., "Enhancing the supervision of community health workers with WhatsApp mobile messaging: qualitative findings from 2 low-resource settings in Kenya," Global Health: Science and Practice, vol. 4, no. 2, pp. 311-325, 2016.

[39] I. Tam, Facebook, WhatsApp Named Top Social Networks. Marketing Magazine, 2015, https://www.marketing-interactive. com/facebook-whatsapp-names-top-social-network-im-hongkong/.

[40] W. Patton and M. McMahon, Career Development and Systems Theory: Connecting Theory and Practice, Sense Publishers, Rotterdam, The Netherlands, 3rd edition, 2014.

[41] A. Yim, S.-W. Wong, and M. Yuen, "Qualitative career assessment approaches in Hong Kong," in Career Assessment: Qualitative Approaches, M. McMahon and M. Watson, Eds., Sense Publishers, Rotterdam, The Netherlands, 2015.

[42] J. C. K. Lee, R. Maclean, and L. Yang, "Life planning vocational and technical educations and secondary schooling in the context of educational reform and socio-economic changes in Hong Kong," in Transitions to Post-School Life: Responsiveness to Individual, Social and Economic Needs, M. Pavlova, J. C. K. Lee, and R. Maclean, Eds., Springer, Singapore, 2018.

[43] T. Cheung and P. S. Yip, "Workplace violence towards nurses in Hong Kong: prevalence and correlates," BMC Public Health, vol. 17, no. 1, p. 196, 2017.

[44] T. Cheung, P. Lee, and P. Yip, "Workplace violence toward physicians and nurses: prevalence and correlates in Macau," International Journal of Environmental Research and Public Health, vol. 14, no. 8, p. 879, 2017.

[45] C. Chung, "Emergency department violence: a local scene," Hong Kong Journal of Emergency Medicine, vol. 10, no. 1, pp. 24-29, 2003.

[46] J. Fleiss, Statistical Methods for Rates and Proportions, Wiley, New York, NY, USA, 1981.

[47] J. C.-K. Lee, M. Pavlova, and R. Maclean, "School-to-work transition in Hong Kong: suggestions for the vocationalization of secondary education," Curriculum and Teaching, vol. 31, no. 1, pp. 47-66, 2016.

[48] OECD, Lessons from PISA for the United States, Strong Performers and Successful Reformers in Education, OECD Publishing, 2011, http://www.oecd.org/pisa/46623978.pdf.

[49] M. Yuen and J. Yau, "Relation of career adaptability to meaning in life and connectedness among adolescents in Hong Kong," Journal of Vocational Behavior, vol. 91, pp. 147-156, 2015.

[50] M. Mourshed, D. Farrell, and D. Barton, Education to Employment: Designing a System that Works, McKinsey \& Company: McKinsey Center for Government, New York, NY, USA, 2013, https://www.mckinsey.com $/ /$ media/McKinsey/ Industries/Social\%20Sector/Our\%20Insights/Education\%20to $\% 20$ employment $\% 20$ Designing $\% 20$ a $\% 20$ system $\% 20$ that $\% 20$ works/Education $\% 20$ to $\% 20$ employment $\% 20$ designing $\% 20$ a $\% 20$ system $\% 20$ that $\% 20$ works.ashx.

[51] A. Tuijnman, "Lifelong learning: evolution of a conceptual map and some implications," in Lifelong Learning in Action: Hong Kong Practitioners' Perspectives, J. Cribbin and P. Kennedy, Eds., Hong Kong University Press, Hong Kong, 2002.

[52] S. Gupta and L. Bashir, "Educational aspiration of secondary school students: influence of school environment and parental 
encouragement international," Journal of Applied Business and Economic Research, vol. 15, no. 2, pp. 1-12, 2017.

[53] D. S. Kaplan, X. Liu, and H. B. Kaplan, "Influence of parents' self-feelings and expectations on children's academic performance," The Journal of Educational Research, vol. 94, no. 6, pp. 360-370, 2001.

[54] A. S. Lawrence and C. Barathi, "Parental encouragement in relation to academic achievement of higher secondary school students," International Journal of Advance Research and Innovative Ideas, vol. 2, no. 6, pp. 1234-1239, 2016.

[55] R. Brooks and G. Everett, "The prevalence of 'life planning': evidence from UK graduates," British Journal of Sociology of Education, vol. 29, no. 3, pp. 325-337, 2008.

[56] S. Hansen and L. Z. Tovar, "Born free to integrated life planning: advancing equity in career development," The Career Development Quarterly, vol. 61, no. 4, pp. 374-378, 2013.

[57] P. J. Palmer, "Divided No more," Change: The Magazine of Higher Learning, vol. 24, no. 2, pp. 10-17, 1992.

[58] R. Brooks, "Youth and lifelong learning," in The Routledge International Handbook of Lifelong Learning, P. Jarvis, Ed., Routledge, London, UK, 2009.

[59] L. Legrain, A. Cleeremans, and A. Destrebecqz, "Distinguishing three levels in explicit self-awareness," Consciousness and Cognition, vol. 20, no. 3, pp. 578-585, 2011.

[60] J. S. Eccles and A. Wigfield, "Motivational beliefs, values, and goals," Annual Review of Psychology, vol. 53, no. 1, pp. 109$132,2002$.

[61] K. Illeris, "Lifelong learning as a psychological process," in The Routledge International Handbook of Lifelong Learning, P. Jarvis, Ed., Routledge, London, UK, 2009.

[62] M. Kucker, "South Dakota's model for career and life planning," Journal of Career Development, vol. 27, no. 2, pp. 133-148, 2000.

[63] T. Hellevik and R. A. Settersten Jr, "Life planning among young adults in 23 European countries: the effects of individual and country security," European Sociological Review, vol. 29, no. 5, pp. 923-938, 2013.

[64] M. Oechsle and B. Geissler, "Between paid work and private commitments," Time \& Society, vol. 12, no. 1, pp. 79-98, 2003.

[65] D. Bowman, J. Borlagdan, and S. Bond, Making Sense of Youth Transitions from Education to Work, Brotherhood of St Laurence, Fitzroy, Victoria, 2015, http://library.bsl.org.au/ jspui/bitstream/1/7764/1/Bowman_et_al_Making_sense_of_ youth_transitions_from_education_to_work_2015.pdf.

[66] Z.-j. Hou and S. A. Leung, "Vocational aspirations of Chinese high school students and their parents' expectations," Journal of Vocational Behavior, vol. 79, no. 2, pp. 349-360, 2011.

[67] M. Morgan, Engaging Parents in the Career Development of Young People, Career Industry Council of Australia (CICA), Australia, 2012.

[68] Y. F. Ho, "Reflections on school career education in Hong Kong: responses to norman C. Gysbers, Darryl Takizo Yagi, and Sang Min Lee \& Eunjoo Yang," Asian Journal of Counselling, vol. 15, no. 2, pp. 183-205, 2008, http://hkier.fed.cuhk.edu.hk/ journal/wp-content/uploads/2009/10/ajc_v15n2_183-205.pdf.

[69] N. C. Gysbers, "Individual student planning in the United States: rationale, practices, and results," Asian Journal of Counselling, vol. 15, no. 2, pp. 117-139, 2008, http://hkier.fed.cuhk.edu.hk/ journal/wp-content/uploads/2009/10/ajc_v15n2_117-139.pdf.

[70] A. Krouska, C. Troussas, and M. Virvou, "SN-Learning: an exploratory study beyond e-learning and evaluation of its applications using EV-SNL framework," Journal of Computer Assisted Learning, vol. 35, no. 2, pp. 168-177, 2019.
[71] C. Troussas, K. Chrysafiadi, and M. Virvou, "Machine learning and fuzzy logic techniques for personalized tutoring of foreign languages," AIED 2018: Artificial Intelligence in Education, pp. 358-362, 2018.

[72] A. Krouska, C. Troussas, and M. Virvou, "A literature review of Social Networking- based Learning Systems using a novel ISO-based framework," Intelligent Decision Technologies, vol. 13, no. 1, pp. 23-39, 2019.

[73] C. Troussas, K. Chrysafiadi, and M. Virvou, "An intelligent adaptive fuzzy-based inference system for computer-assisted language learning," Expert Systems with Applications, vol. 127, pp. 85-96, 2019. 


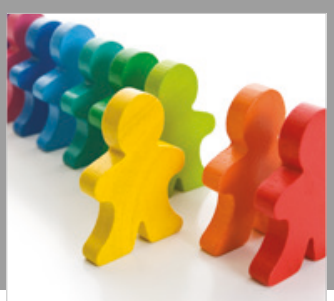

Autism

Research and Treatment
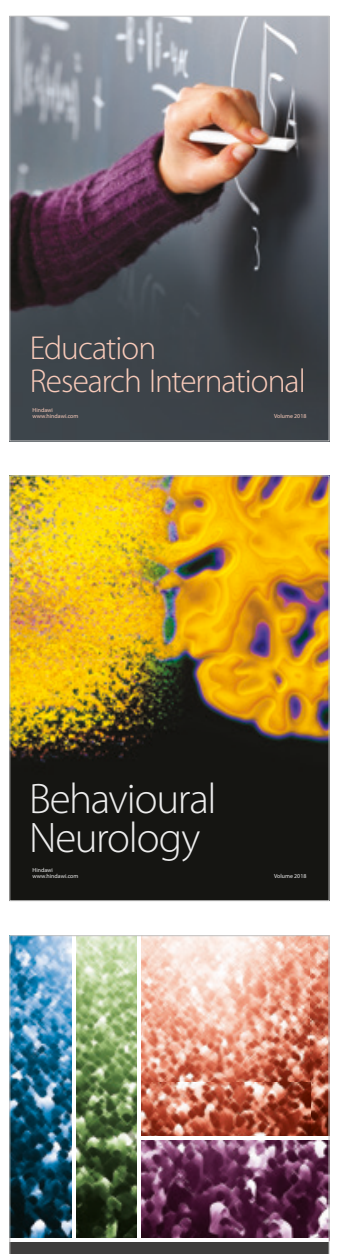

International Journal of

Population Research

$\underline{-m}$

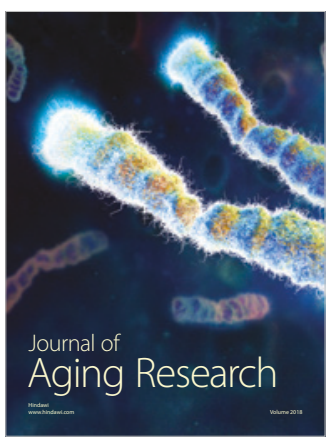

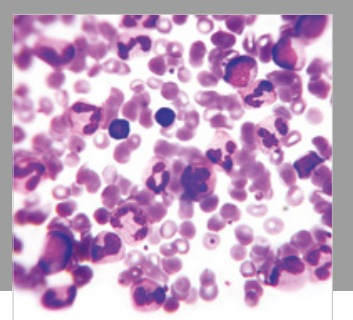

Pathology

Research International$$
=
$$

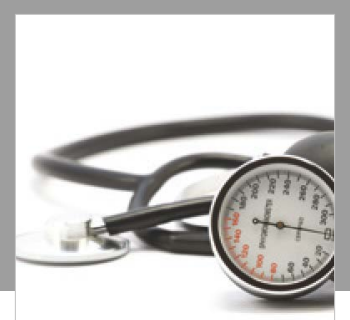

Nursing

Research and Practice

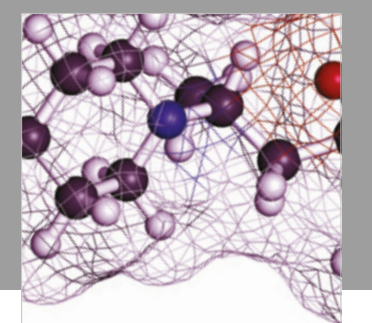

Pain

Research and Management

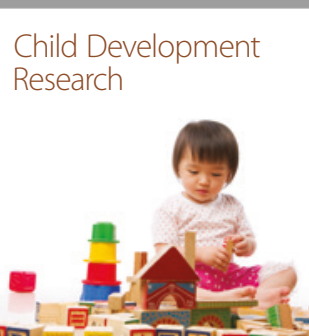

बाD

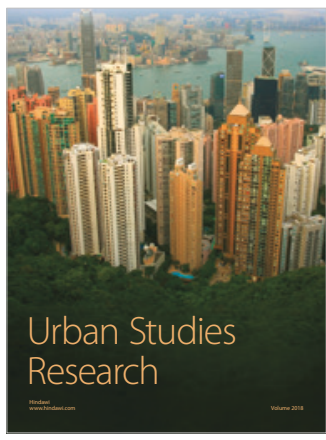

\section{Hindawi}

Submit your manuscripts at

www.hindawi.com
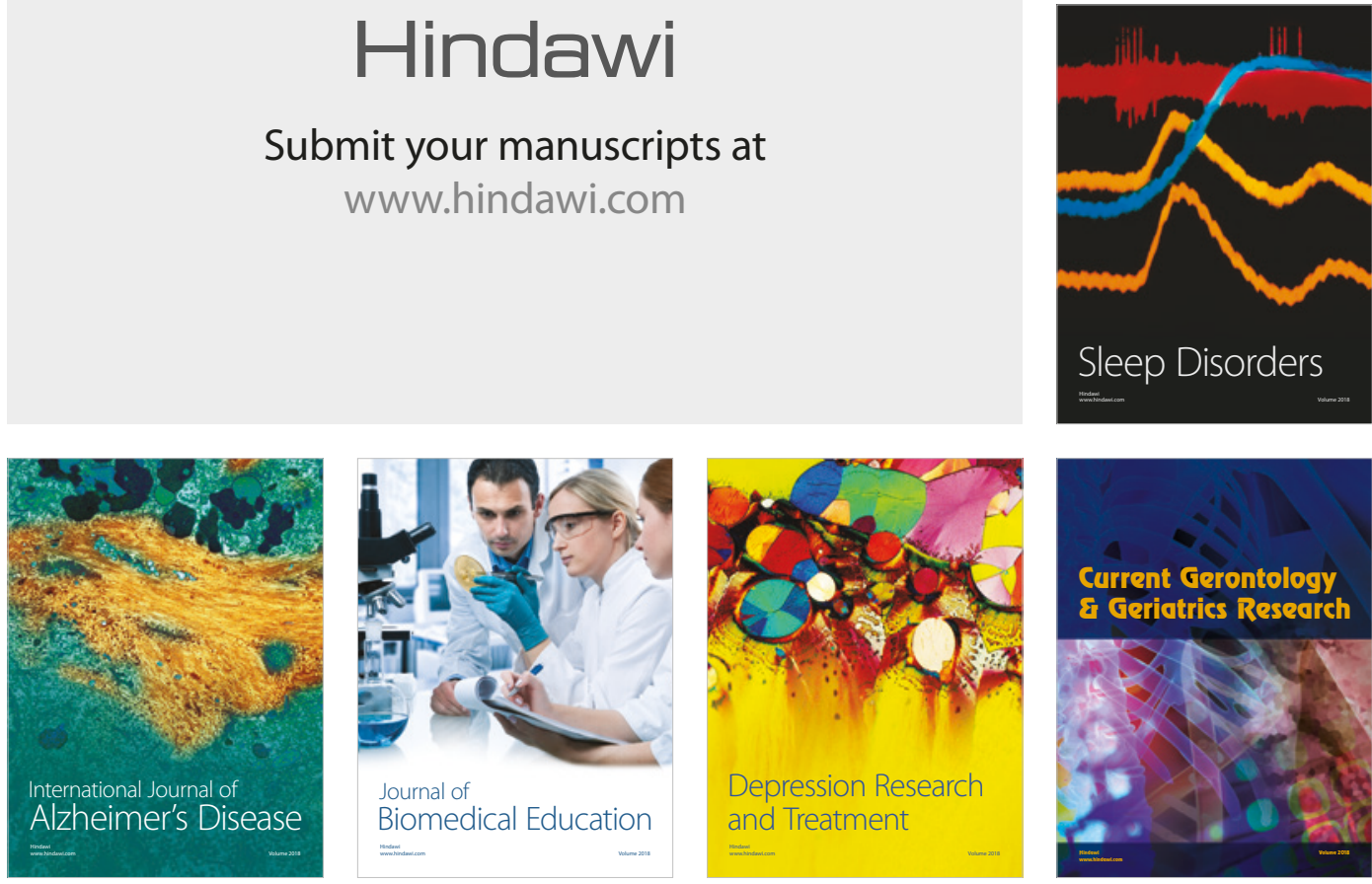

Journal of

Biomedical Education

$=$

smman

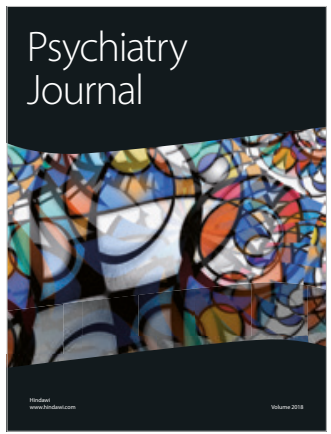

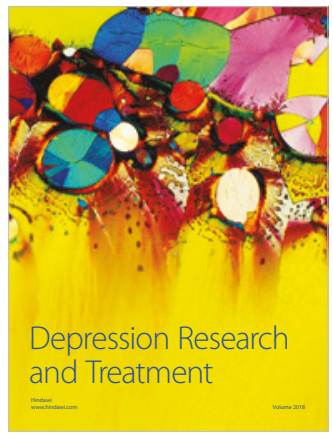
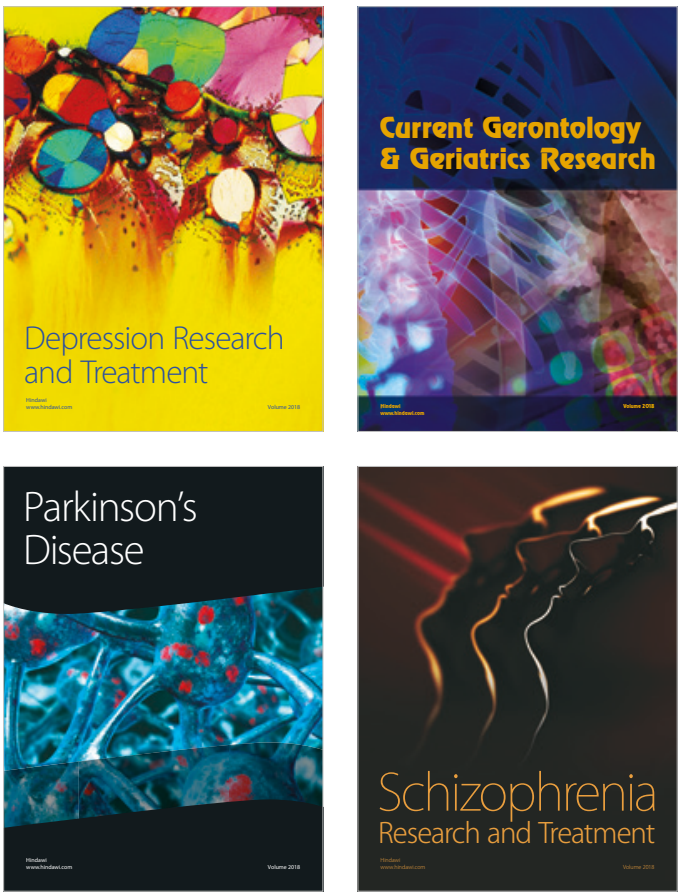